\title{
ADSORPTION REMOVAL OF ERIOCHROME BLACK T (EBT) AND ROSE BENGAL (RB) FROM AQUEOUS SOLUTIONS USING BIO-SORBENTS COMBINATION
}

\author{
Miada Benkartoussa ${ }^{1,}$, Mossaab Bencheikh Lehocine ${ }^{1}$, Sihem Arris ${ }^{1}$, \\ Hassen Abdeslam Meniai ${ }^{1}$
}

https://doi.org/10.23939/chcht15.02.299

\begin{abstract}
Adsorption of eriochrome black T (EBT) and rose bengal (RB) mixture from aqueous solutions was investigated using a mixture of low-cost biosorbents $50 \%$ of raw state potato peels and $50 \%$ of raw state eggshell (M 50\%). The surface charge distribution was determined by acid-base titration and the point of zero charge of the M $50 \%$ was found to be 8.5 . The adsorbent materials were characterized by Fourier transform infrared spectroscopy and X-ray diffraction. It was confirmed that M 50\% was mainly composed of calcite and cellulose. The effect of various operating parameters such as contact time, $\mathrm{pH}$, temperature, etc., was studied. The amount of the adsorption decreased when solution $\mathrm{pH}$ increased. The pseudo-second order kinetic model provided the best fit to the experimental data for the adsorption of EBT and RB. The obtained thermodynamic parameters indicate that the adsorption process is endothermic one. According to the obtained results, the new biosorbent may be recommended as an industrial adsorbent for the treatment of effluents containing EBT and RB.
\end{abstract}

Keywords: dye, combination, adsorbent, valorize.

\section{Introduction}

In several industries like textile, paper, food, plastic, leather, etc. synthetic dyes have been widely used. The varieties of the dyes are: acidic, reactive, basic, azo, and diazo [1]. These dyes are non-biodegradable due to their toxic nature [2], the elimination of pollutants and colored effluents from wastewater is important for protecting public health and the environment [3]. There

\footnotetext{
${ }^{1}$ Environmental Process Engineering Laboratory (LIPE), Department of Environmental Engineering,

University Salah Boubnider, Constantine, Algeria

\benkartoussa@yahoo.fr

(c) Benkartoussa M., Bencheikh Lehocine M., Arris S., Meniai H., 2021
}

are many traditional techniques applied in the dye removal such as coagulation, flocculation, photo degradation, sedimentation [4], ion exchange, and membrane filter processes such as micro- and ultra-filtration and reverse osmosis. These methods are expensive, use chemical products and generate large amounts of sludge [5]. Among these methods, adsorption is superior to other techniques, which are used on industry scale and are environmentally friendly [6]. Because of its low cost and simplicity adsorption has made an important advance in the elimination of colored effluents [7]. The development of new adsorbents, free and abundant, which compete with an expensive adsorbents, such as activated carbon granules or powder, encourages the use of these free biosorbents as an effective solution [8]. A number of these adsorbents are reported in the literature, like fly ash, sawdust, lignite, rice husk, banana pit, potato peels, raw state, and eggshells [2, 7]. The extent of dye removal depends upon the kind of dye, nature of adsorbent and experimental conditions [9].

In reality the colored effluents are in the form of a mixture of dyes, so in the present work, a study was made for the mixture of two dyes: eriochrome black T (EBT) and rose bengal (RB) by raw state potato peels (PPRS) and raw state eggshells (EGRS) to illustrate the value of these bio-sorbents and their use in dye wastewater treatment. The adsorption of dyes is better on the raw state eggshells, and similar to the adsorbent M 50\%: (50\% of PPRS $+50 \%$ of EGRS) but low on raw state potato peels. So, the raw state potato peel was estimated by the addition of the raw state eggshells, because the addition of EGRS on PPRS (M 50\%) has to increase the adsorption capacity of PPRS compared to this adsorbent alone, the M 50\% was chosen for the following works. Several parameters of the adsorption phenomenon will also be discussed, such as: $\mathrm{pH}$, effect of ionic strength, adsorption kinetics models, etc., not forgetting chemical analysis of adsorbents and characterization of adsorbent materials. 


\section{Experimental}

\subsection{Preparation of Adsorbents}

\subsubsection{Adsorbents at raw state}

Potato peels and eggshells were washed with distilled water and cut into small parts, and then dried at $333 \mathrm{~K}$ for 3 days. The obtained product was crushed into granules, sieved to the particle size of $0.315 \mathrm{~mm}$ with sifter (ANALYSENSIEB- RETSH-5657 HAANW) and stored in desiccators. eggshell

- PPRS: raw state potato peels, EGRS: raw state

\subsubsection{Adsorbent mixture}

The biosorbents mixture contained raw state potato peels (PPRS) and raw state eggshell (EGRS) with different proportions, as follows:

- $\mathrm{M} 25 \%=25 \%$ of EGRS $+75 \%$ of PPRS

- $\mathrm{M} 50 \%=50 \%$ of EGRS $+50 \%$ of PPRS

- $\mathrm{M} 75 \%=75 \%$ of EGRS $+25 \%$ of PPRS

\subsection{Chemical Analyses of Adsorbents}

$100 \mathrm{mg}$ of adsorbent was placed in $10 \mathrm{ml}$ of $0.1 \mathrm{M} \mathrm{NaCl}$ solution. The suspension was shaken for 3 days. The solution was then filtered to determine the $\mathrm{pH}_{\text {cont }}$. $\mathrm{NaCl}$ is a carrier electrolyte allowing to make the migration current of the species negligible in front of diffusion, so the measurement of $\mathrm{pH}$ is more stable.

The $\mathrm{pH}$ point of zero charge $\left(\mathrm{pH}_{\mathrm{pzc}}\right)$ for the adsorbents were determined by adding $100 \mathrm{mg}$ of adsorbent to four solutions $0.1 \mathrm{M} \mathrm{NaCl}(20 \mathrm{ml})$, which initial $\mathrm{pH}$ is close to the $\mathrm{pH}_{\text {cont, }}$ which has been measured and adjusted with $\mathrm{NaOH}$ or $\mathrm{HCl}$. The solutions were shaken for $24 \mathrm{~h}$. The $\mathrm{pH}_{\mathrm{pzc}}$ corresponds to the value of $\mathrm{pH}$ when there is no change of this parameter after contact with adsorbent [10]. At the solution $\mathrm{pH}_{\mathrm{pzc}}>\mathrm{pH}$, the support surface is positively charged, when $\mathrm{pH}_{\mathrm{pzc}}<\mathrm{pH}$, the surface will be negative [11].

\subsection{Analyses}

FT-IR spectrometer BRUKER was used to know various functional groups of the adsorbent using potassium bromide disk method, the FT-IR spectra were recorded at $5000-500 \mathrm{~cm}^{-1}$ [11]; X-ray diffraction (XRD) data were obtained by a diffractometer X Pert Pro Panalytical, XRD was used to know the nature and structure of crystallized adsorbent [12].

\subsection{Adsorbates Properties}

The chemical properties and structures of eriochrome black $\mathrm{T}(\mathrm{EBT})$ and rose bengal (RB) are presented in Table 1.

The dye solution was prepared by dissolving a mass of dye powder in a known volume of distilled water.

Table 1

Characteristics of EBT and RB

\begin{tabular}{|c|c|c|}
\hline Characteristics & EBT & RB \\
\hline IUPAC name & $\begin{array}{l}\text { Sodium 1-[1-Hydroxynaphthylazo]-6- } \\
\text { nitro-2-naphthol-4-sulfonate }\end{array}$ & $\begin{array}{c}\text { 4,5,6,7-Tetrachloro-3',6'-dihydroxy- } \\
\text { 2',4',5',7'-tetraiodo-3H- } \\
\text { spiro[isobenzofuran-1,9'-xanthen]-3-one }\end{array}$ \\
\hline Type of dye & Anionic (acid) azo dye & Anionic (acid) azo dye \\
\hline Chemical formula & $\mathrm{C}_{20} \mathrm{H}_{12} \mathrm{~N}_{3} \mathrm{NaO}_{7} \mathrm{~S}$ & $\mathrm{C}_{20} \mathrm{H}_{2} \mathrm{Cl}_{4} \mathrm{I}_{4} \mathrm{Na}_{2} \mathrm{O}_{5}$ \\
\hline \multicolumn{3}{|l|}{ Molecular structure } \\
\hline Molecular weight, $\mathrm{g} / \mathrm{mol}$ & 461.38 & 1017.64 \\
\hline Max. wavelength, nm & 531 & 541 \\
\hline Solubility in water at $293 \mathrm{~K}, \mathrm{~g} / \mathrm{l}$ & 50.0 & - \\
\hline Solubility in ethanol at $293 \mathrm{~K}, \mathrm{~g} / \mathrm{l}$ & 2.0 & - \\
\hline Color & black & - \\
\hline The commercial origin & Merck (Germany) & Biochem, Chemopharma (Quebec) \\
\hline
\end{tabular}




\subsection{Batch Mode Adsorption}

The study of adsorption was carried out in batch to determine the adsorption of RB and EBT on M $50 \%$. Tests were performed by agitating adsorbents and dye solutions with different initial concentrations (12.5$90 \mathrm{mg} / \mathrm{l})$. Mixing was ensured with the agitation speed of $500 \mathrm{rpm}$ for $15-120 \mathrm{~min}$ at $293 \pm 2 \mathrm{~K}$. After the equilibrium, the suspension was filtered with a $0.2 \mu \mathrm{m}$ millipore filter and analyzed using a Jasco V-630 spectrophotometer and via a standard calibration curve. The effect of contact time and $\mathrm{pH}$ was studied. The $\mathrm{pH}$ of the suspension in the experiments was adjusted with $0.1 \mathrm{M} \mathrm{NaOH}$ or $0.1 \mathrm{M} \mathrm{HCl}$. The amount of EBT or RB adsorbed onto M 50\% and the removal efficiency $R$ were respectively calculated using the following equations:

$$
\begin{gathered}
q=\frac{\left(C_{0}-C\right)}{m} V \\
R=\frac{\left(C_{0}-C\right)}{C_{0}} \cdot 100
\end{gathered}
$$

where $C_{0}$ and $C$ are the dye initial concentration and concentration at time $t$, respectively, $\mathrm{mg} / \mathrm{l} ; V$ is the dye solution volume, $1 ; m$ is the adsorbent mass, $g$.

\subsection{Adsorption Kinetics Models}

Adsorption kinetics is essential in process design since it determines the rate of retention and the necessary time to achieve a certain amount of removal.

\subsubsection{Pseudo-first order model}

It has been assumed in this model that the sorption rate at instant $t$ is proportional to the difference between the adsorbed quantity at equilibrium $\left(q_{e}\right)$ and time $t\left(q_{t}\right)$, moreover the adsorption is reversible. This model was established by Langeren and Svenska [13]. It can be expressed in a linear form as follows:

$$
\frac{d q_{t}}{d t}=K_{1} \cdot\left(q_{e}-q_{t}\right)
$$

where $q_{e}$ and $q_{t}$ are the amount of adsorbate adsorbed at equilibrium and time $t(\mathrm{~min})$, respectively, $\mathrm{mg} / \mathrm{g} ; K_{1}$ is the adsorption rate constant, $\min ^{-1}$.

The integration of Eq. (3) for the boundary conditions $t=0$ to $t$ and $q_{t}=0$ to $q_{t}$, gives:

$$
\ln \left(q_{e}-q_{t}\right)=\ln q_{e}-K_{1} t
$$

The following plot of $\ln \left(q_{e}-q_{t}\right)$ vs. $t$ will give the slope $K_{1}$ and the intercept $\ln q_{e}$.

\subsubsection{Pseudo-second order model}

The pseudo-second order model is destined for the description of adsorption kinetics in liquid-phase adsorption systems; this model is proposed by Ho and McKay [13]. The linear form of pseudo second order model is expressed as follows:

$$
\frac{t}{q_{t}}=\frac{1}{K_{2} \cdot q_{e 2}^{2}}+\frac{1}{q_{e 2}} t
$$

where $K_{2}$ is the adsorption rate constant, $\mathrm{g} \cdot \mathrm{mg}^{-1} \cdot \mathrm{min}^{-1}$.

The linear plot of $t / q_{t} v s . t$ will give $1 / q_{e 2}$ as slope and $1 / K_{2} q_{e 2}{ }^{2}$ as the intercept.

\subsubsection{The intraparticle diffusion model}

The Weber and Moriss model allows the identification of the diffusion mechanism if it is present; the kinetic results were analyzed using the intraparticle diffusion model [14], which is expressed as:

$$
q_{t}=K_{i n}{ }^{0.5}+C_{\text {in }}
$$

where $K_{i n}$ is an intraparticle diffusion constant, $\mathrm{mg} / \mathrm{g} \cdot \mathrm{min}^{0.5} ; C_{\text {in }}$ is the intercept, it is directly proportional to the boundary layer thickness, $\mathrm{mg} / \mathrm{g}$.

The linear plot of $q_{t} v$ s. $t^{0.5}$ will give $K_{\text {in }}$ as slope and $C_{i n}$ as the intercept.

\subsection{Isotherm Analyses}

\subsubsection{Langmuir isotherm} [15]:

The Langmuir isotherm model is given as Eq. (7)

$$
\frac{1}{q_{e}}=\frac{1}{q_{0}}+\frac{1}{q_{0} b} \cdot \frac{1}{C_{e}}
$$

where $C_{e}$ is the concentration of the dye solution at equilibrium, $\mathrm{mg} / \mathrm{l} ; q_{0}$ is a practical limiting adsorption capacity; $b$ is the Langmuir constant, $1 / \mathrm{mg}$.

\subsubsection{Freundlich isotherm}

The linear form of the Freundlich equation is:

$$
\ln q_{e}=\ln K_{F}+\frac{1}{n} \ln C_{e}
$$

where $n$ represents the adsorption intensity and $K_{F}$ is an indicator of the multilayer adsorption capacity, $\mathrm{mg} / \mathrm{g}(\mathrm{mg} / \mathrm{l})^{1 / \mathrm{n}}[16]$. It is usually admitted that values of $n>1$ proved the favorable adsorption [17].

\subsection{Effect of Temperature}

The adsorption can be endothermic or exothermic depending on the adsorbent materials and the nature of the adsorbed molecules as well. To understand the thermodynamic phenomenon of EBT and RB adsorption onto $\mathrm{M} 50 \%$ the tests were conducted at the concentration of $25 \mathrm{mg} / \mathrm{l}$ and the temperatures ranged from 293 to $353 \mathrm{~K}$. The thermodynamic parameters $\Delta G, \Delta H$ and $\Delta S$ were determined using the following equations:

$$
\begin{gathered}
K_{d}=\frac{q_{e}}{C_{e}} \\
\Delta G=-R T \ln K_{d}
\end{gathered}
$$




$$
\ln K_{d}=\frac{\Delta S}{R}-\frac{\Delta H}{R T}
$$

where $K_{d}$ is the equilibrium constant for adsorption; $T$ is the temperature, $\mathrm{K} ; R$ is the universal gas constant; $\Delta G$, $\Delta H, \Delta S$ are Gibbs free energy change, enthalpy and entropy change of the process, respectively.

The values of $\Delta H$, and $\Delta S$ are calculated from the slope and intercept of the plot $\ln K_{d} v s .1 / T$ [18].

\section{Results and Discussion}

Removal of anionic dyes EBT and RB by the mixture of adsorbents $\mathrm{M} 50 \%$ from aqueous solution was carried out. Chemical analysis of adsorbents and adsorbents characterization were made. Effect of various parameters such as contact time, $\mathrm{pH}$, ionic strength and temperature, adsorption kinetics models, and isotherm analysis on the adsorption capacity of dyes was studied.

\subsection{Adsorbents Characterization}

The FT-IR spectrum of the adsorbent M $50 \%$ is shown in Fig. 1; the functional groups are presented in Table 2.

According to Fig.1 and Table 2, the peak around $3300 \mathrm{~cm}^{-1}$ occurs due to a stretching vibration of the $\mathrm{O}-\mathrm{H}$ bond in the cellulose, which is part of the PPRS composi- tion [11]; the peak at $1400 \mathrm{~cm}^{-1}$ occurs due to the stretching of the $\mathrm{C}-\mathrm{O}$ bond in the carbonate $\mathrm{CO}_{3}{ }^{-2}$, an important component of EGRS [19], the remaining picks are identified in Table 2.

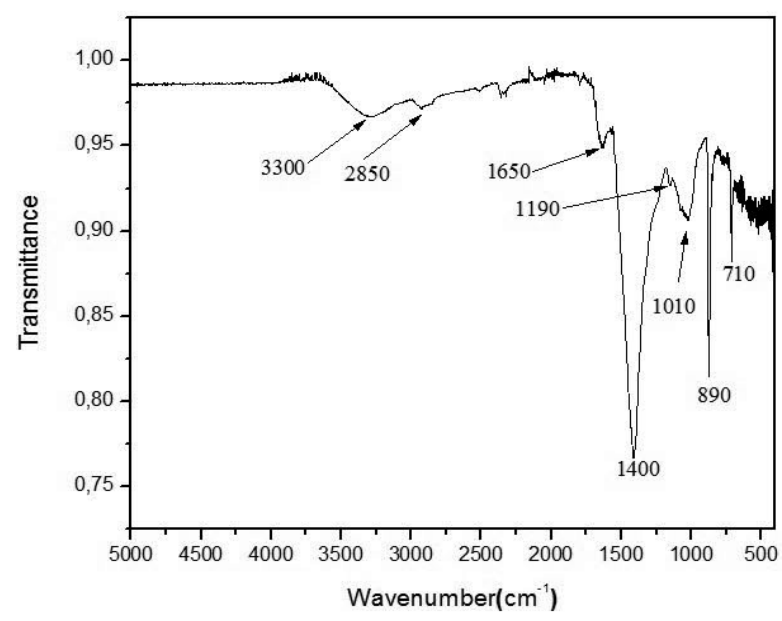

Fig. 1. FT-IR spectrum of M $50 \%$

The XRD pattern for M 50\% is presented in Fig. 2. The distinctive peaks of the XRD pattern were identified as the crystalline phase of $\mathrm{CaCO}_{3}$ in the calcite form. It can be seen that the eggshell sample in $\mathrm{M} 50 \%$ is composed of $\mathrm{CaCO}_{3}[19]$.

Table 2

The functional groups of M 50\%

\begin{tabular}{|c|c|c|c|}
\hline Wavenumber, $\mathrm{cm}^{-1}$ & Vibration & Probable groupings & Ref. \\
\hline 3300 & stretching & O-H bond related to cellulose & {$[20],[11]$} \\
\hline 2850 & asymmetric stretching & $\mathrm{C}-\mathrm{H}$ bond presented in methyl group & {$[20],[11]$} \\
\hline 1650 & stretching & $\mathrm{C}=\mathrm{O}$ bond in the secondary amide & {$[21],[22]$} \\
\hline 1400 & stretching & $\mathrm{C}-\mathrm{O}$ bond corresponding to the carbonate $\mathrm{CO}_{3}{ }^{-2}$ & {$[19]$} \\
\hline 1190 & stretching & $\mathrm{C}-\mathrm{O}$ bond related to a lignin & {$[20],[11]$} \\
\hline 1010 & stretching & $\mathrm{C}-\mathrm{O}-\mathrm{C}$ bond in the cellulose & {$[11]$} \\
\hline $890-710$ & deformation & Due to the out-of-plane and in-plane deformation modes of carbonate & {$[19]$} \\
\hline
\end{tabular}

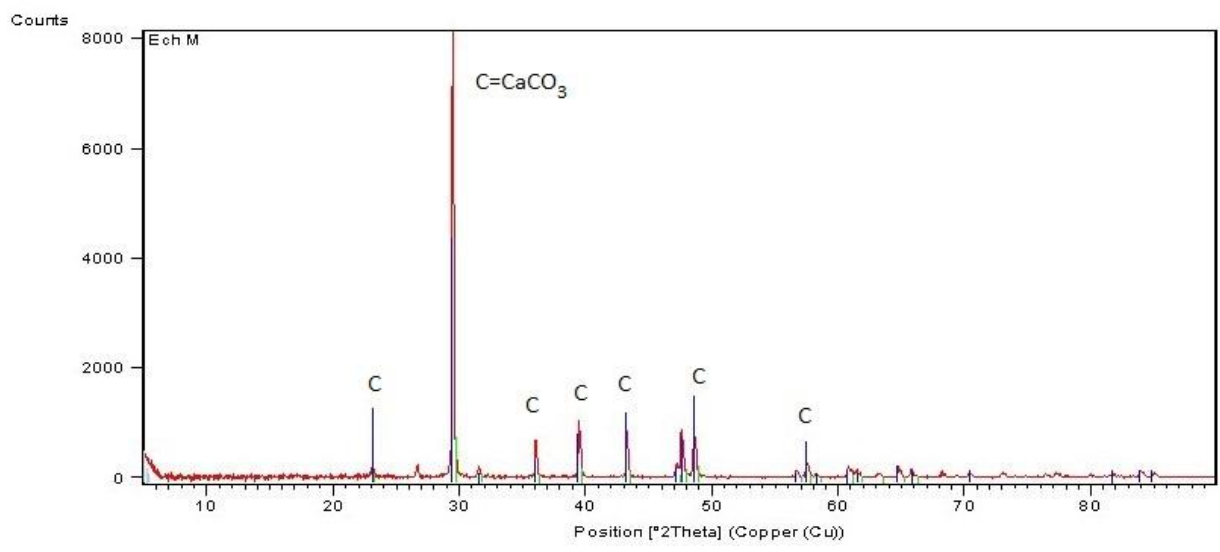

Fig. 2. Typical X-ray diffraction pattern for M $50 \%$ 


\subsection{Effect of Operating Parameters}

\subsubsection{Effect of contact time}

Fig. 3 illustrates the removal efficiency $R$ of EBT and $\mathrm{RB}$ with the initial concentration of $25 \mathrm{mg} / 1$ on different adsorbents (PPRS, EGRS, M 25\%, M 50\% and $\mathrm{M} 75 \%$ ). For EBT and RB, the removal efficiencies using EGRS, $\mathrm{M} 50 \%$ and $\mathrm{M} 75 \%$ have the same value and it is higher compared to PPRS. For example, when EGRS is mixed with PPRS (M 50\%) an increase in the removal efficiency is from 35 to $63 \%$ for EBT and from 60 to $90 \%$ for RB. The obtained values of the removal efficiencies were close to the EGRS one; the mixture of EGRS and PPRS (M 50\%) has to rise the amount of adsorption for the latter one (PPRS). Therefore, the PPRS was considerably valued by the addition of EGRS to PPRS.

Clearly, since, the adsorption process shows the transfer of the pollutant from the liquid phase to the solid one, the contact time between two phases has an effect on the mass transfer rate. Consequently, it is important to study its effect on the capacity of retention by M $50 \%$ (Fig. 3).

This variation shows clearly that the curves are of a saturation type and the chemical equilibrium was attained for EBT and RB after 80 and 20 min, respectively; during the adsorption of RB, the saturation curves rises sharply in the initial stages, indicating that there are a great number of readily accessible vacant sites in biosorbent M 50\% [23], unlike for EBT, there is a phenomenon of filling layer by layer. Therefore, an equilibrium time of $120 \mathrm{~min}$ was assumed for all further experimental runs.

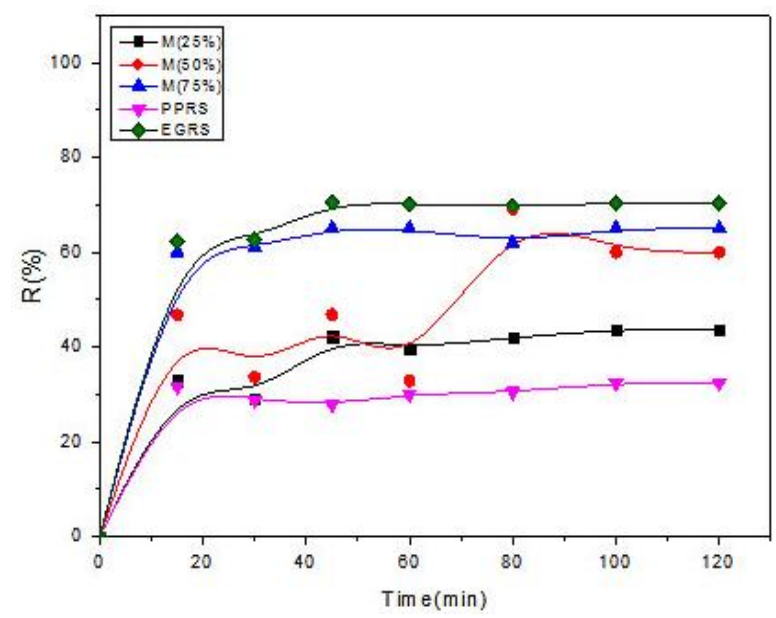

a)

\subsubsection{Effect of $\mathrm{pH}$}

The solution $\mathrm{pH}$ is important for its effect on the adsorbent and sorbate. In this study, the adsorption of EBT and $\mathrm{RB}$ on $\mathrm{M} 50 \%$ was carried within $\mathrm{pH}$ from 3.01 to 11.75 .

Fig. 4 shows the obtained results. When EBT $\mathrm{pH}$ increases from 3.01 to 5.3 the adsorption capacity raises from 2.4 to 2.6 ; while $\mathrm{pH}$ varies from 5.3 to 8.65 the adsorption capacity decreases from 2.6 to 1.7 ; the adsorption capacity is not change with the variation of $\mathrm{pH}$ from 8.65 to 11.75 (Fig. 4b).

Fig. 4c [24] shows that EBT is an anionic dye. When $\mathrm{pH}$ increases from 3.01 to 5.3 the adsorbent surface charge of $\mathrm{M} \mathrm{50 \%}$ is positive according to $\mathrm{pH}_{\mathrm{pzc}}$ in Table 3 and Fig. $4 \mathrm{~d}$. Therefore, the attraction between the dye and the adsorbent is very important and the amount of adsorption is important as well. For the $\mathrm{pH}$ range of 5.38.65 the adsorbent surface charge is positive and the coloring solution is overloaded with $\left[\mathrm{OH}^{-}\right]$, so the amount of adsorption will decrease due to the competition between anionic dye (EBT) and [OH] [25]. However, for the $\mathrm{pH}$ variation from 8.65 to 11.75 the amount of adsorption did not vary, and this is due to the phenomenon of ion exchange or complexation [26].

Table 3

\section{Characteristics of different adsorbents}

\begin{tabular}{|c|c|c|}
\hline Adsorbent & $\mathrm{pH}_{\text {cont }}$ & $\mathrm{pH}_{\mathrm{pzc}}$ \\
\hline PPRS & 8.37 & 8.06 \\
\hline EGRS & 8.28 & 8.56 \\
\hline M $50 \%$ & 8.43 & 8.5 \\
\hline
\end{tabular}

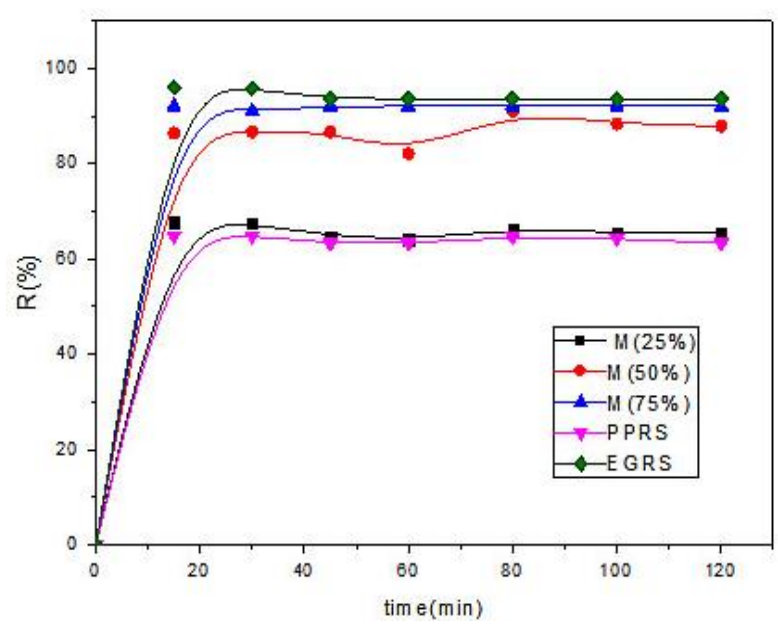

b)

Fig. 3. Effect of contact time on the adsorption of EBT (a) and RB (b). Conditions: $C_{0}=25 \mathrm{mg} / \mathrm{l}$, stirring speed $=500 \mathrm{rpm}$, sorbent dosage $=0.6 \mathrm{~g}\left(100 \mathrm{ml}^{-1}\right), T=293 \pm 2 \mathrm{~K}, \mathrm{pH}=6.4, d<0.315 \mathrm{~mm}$ 


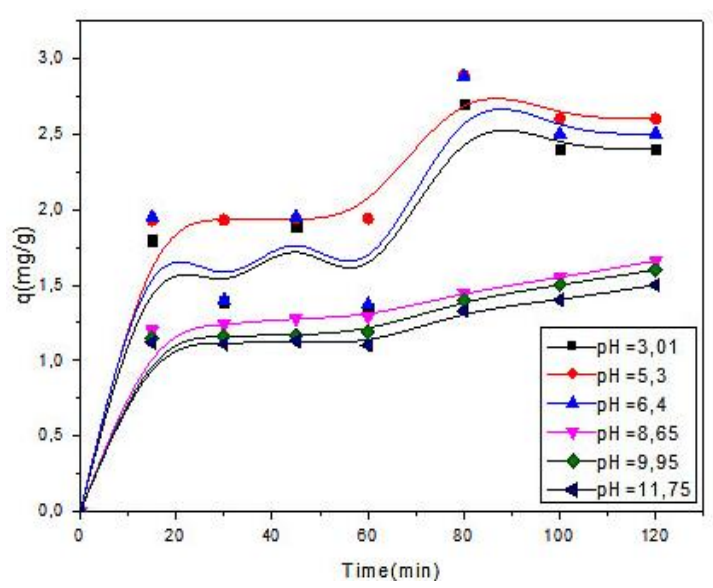

a)

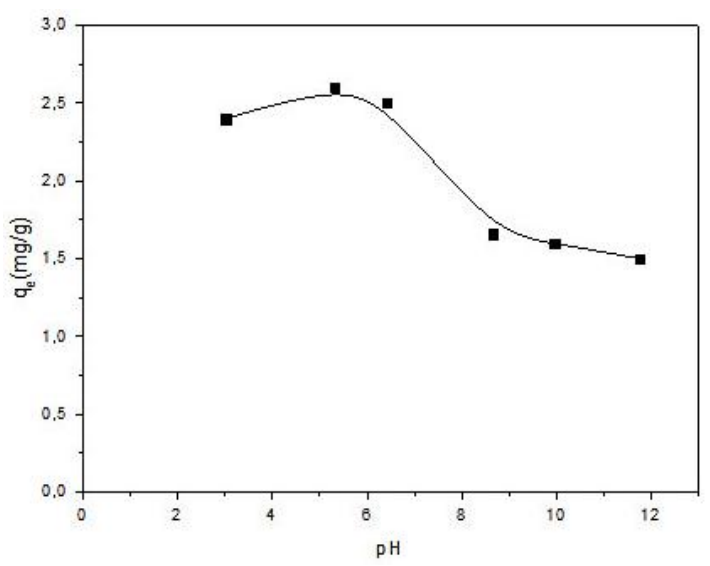

b)

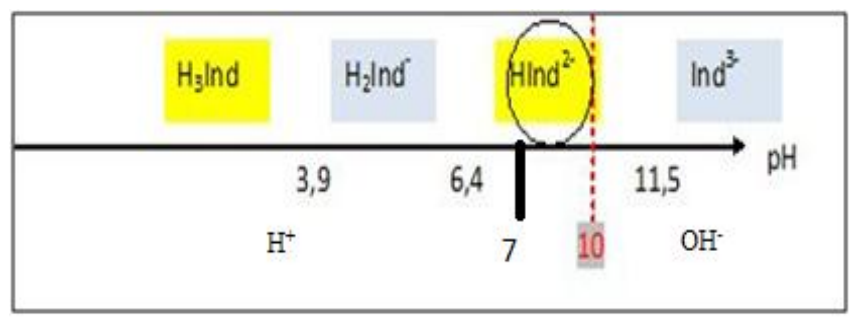

c)

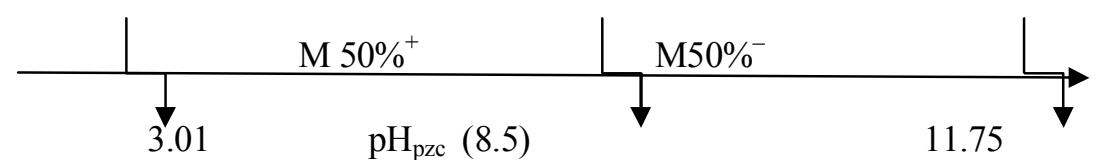

d)

Fig. 4. Effect of $\mathrm{pH}$ on EBT (a); pH $v$ s. capacity $q_{e}(\mathrm{~b})$; distribution of chemical species of EBT (c); charge of M $50 \%$ surface. Conditions: $C_{0}=25 \mathrm{mg} / \mathrm{l}$, stirring speed $=500 \mathrm{rpm}$, sorbent dosage $=0.6 \mathrm{~g}\left(100 \mathrm{ml}^{-1}\right), T=293 \pm 2 \mathrm{~K}, d<0.315 \mathrm{~mm}$

According to Fig. $5 \mathrm{~b}$ the increase in $\mathrm{pH}$ from 3.01 to 11.75 for $\mathrm{RB}$ decreases the amount of adsorption from 3.83 to 2.6. The RB is an anionic dye [27]. When $\mathrm{pH}$ increases, the adsorbent surface charge became more and more negative, so the repulsive forces between the dye and adsorbent became more important, resulting in a decreased adsorption [25].

\subsubsection{Effect of ionic strength}

The effect of ionic strength on adsorption has been investigated in this work. It was studied by the addition of $\mathrm{NaCl}$ or $\mathrm{ZnCl}_{2}$ in the colored solution of EBT and $\mathrm{RB}$ $(25 \mathrm{mg} / \mathrm{l})$ at different concentrations $(0.1 \mathrm{M}$ and $0.3 \mathrm{M})$.

The addition of salt increases considerably the adsorbed amount of dyes from 1.17 to $20 \mathrm{mg} / \mathrm{g}$ for EBT and from 1.82 to $25 \mathrm{mg} / \mathrm{g}$ for RB (Fig. 6), it can be attributed to the aggregation of dye molecules induced by the action of salt ions $\left(\mathrm{NaCl}\right.$ or $\left.\mathrm{ZnCl}_{2}\right)$ and the decrease of mutual repulsive forces between the dye and the adsorbent [28].

\subsubsection{Adsorption kinetics models}

The plot of $\ln \left(q_{e}-q_{t}\right) v s$. $t$, for both dyes and for the different initial concentrations is shown in Figs. 7a and 8a. Tables 4 and 5 summarize the obtained fitting results. As the difference between experimental $q_{e}$ and first order simulated $q_{e}$ is considerable, the obtained correlation coefficient values are very small; consequently the adsorption is not the first order reaction. 


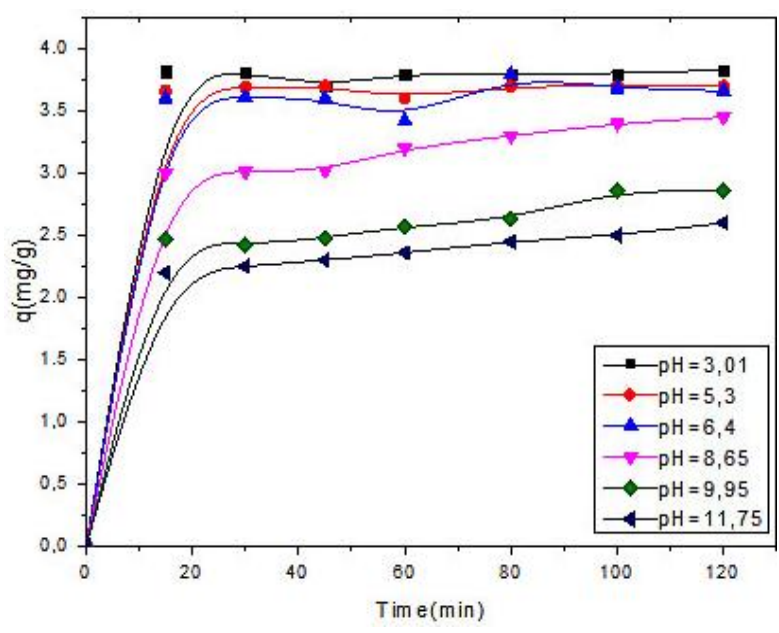

a)

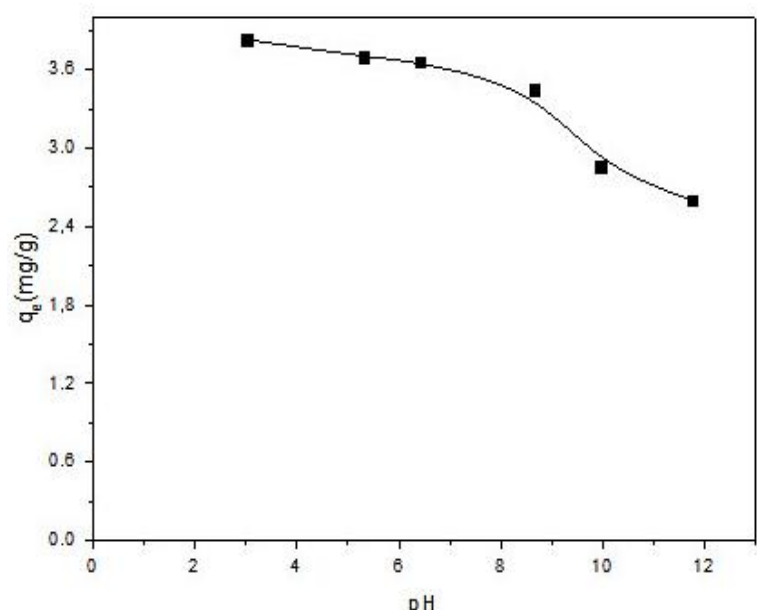

b)

Fig. 5. Effect of $\mathrm{pH}$ on $\mathrm{RB}(\mathrm{a})$ and variation of $\mathrm{pH} v$ s. capacity $q_{e}(\mathrm{~b})$.

Conditions: $C_{0}=25 \mathrm{mg} / \mathrm{l}$, stirring speed $=500 \mathrm{rpm}$, sorbent dosage $=0.6 \mathrm{~g}\left(100 \mathrm{ml}^{-1}\right), T=293 \pm 2 \mathrm{~K}, d<0.315 \mathrm{~mm}$

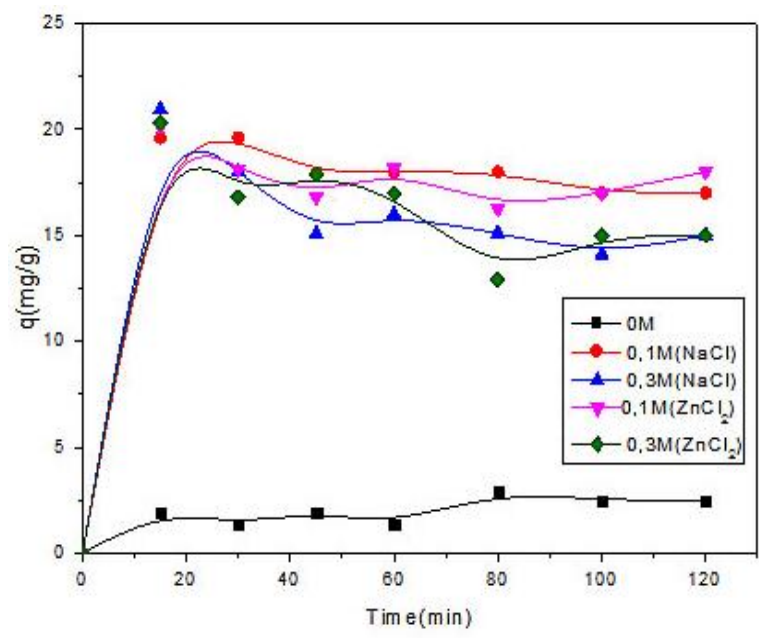

a)

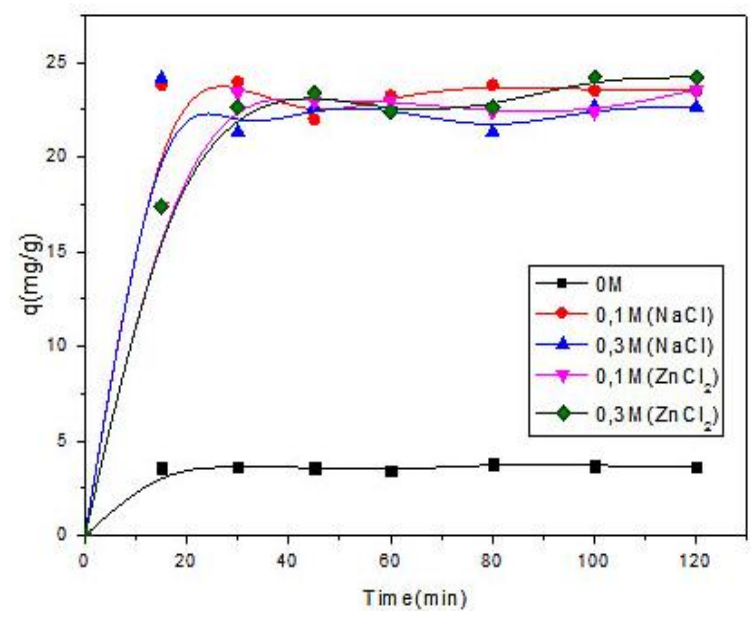

b)

Fig. 6. Effect of EBT (a) and RB (b) ionic strength.

Conditions: $C_{0}=25 \mathrm{mg} / \mathrm{l}$, stirring speed $=500 \mathrm{rpm}$, sorbent dosage $=0.6 \mathrm{~g}\left(100 \mathrm{ml}^{-1}\right), T=293 \pm 2 \mathrm{~K}, \mathrm{pH}=6.4, d<0.315 \mathrm{~mm}$

Due to the non-applicability of the pseudo-first order model to experimental data, they have been tested with the second order kinetic model by plotting $t / q_{t} v s . t$ (Figs. $7 \mathrm{~b}$ and $8 \mathrm{~b}$ ). The fitting results are collected in Tables 4 and 5 , the rate constant $K_{2}$ was found to be decreased from 0.1736 to 0.00813 with the increase in the initial dye concentration from 12.5 to $90 \mathrm{mg} / \mathrm{l}$ for RB. Moreover, plot correlation coefficients are closer to one, furthermore, the difference between experimental $q_{e}$ and second order simulated $q_{e}$ is insignificant, as given in Table $6\left(C_{0, \text { EBT }}=12.5 \mathrm{mg} / 1, q_{e, \text { exp }}=1.17 \mathrm{mg} / \mathrm{g}, q_{e, \text { calc }}=\right.$ $=1.33 \mathrm{mg} / \mathrm{g}$ ). It implies that the adsorption of EBT and
$\mathrm{RB}$ on biosorbent $\mathrm{M} 50 \%$ is well described by the pseudosecond order kinetic model.

Figs. $7 \mathrm{c}$ and $8 \mathrm{c}$ show the representation of $q_{t} v s$. the time square root of the tested concentrations and indicate that the diffusion within the pores is involved in the sorption process but not as the only limiting mechanism. We have two regions: the diffusion in the pores (intraparticle diffusion) and finally the last step which represents the equilibrium (the intraparticle diffusion begins to slow down). The values of $C_{\text {in }}$ increase when the concentration raises (Tables 4, 5) [29]. 


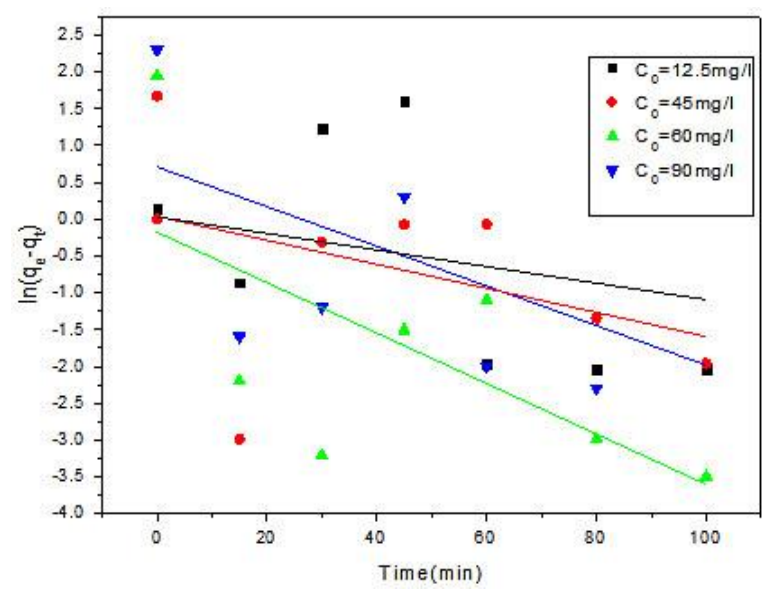

a)

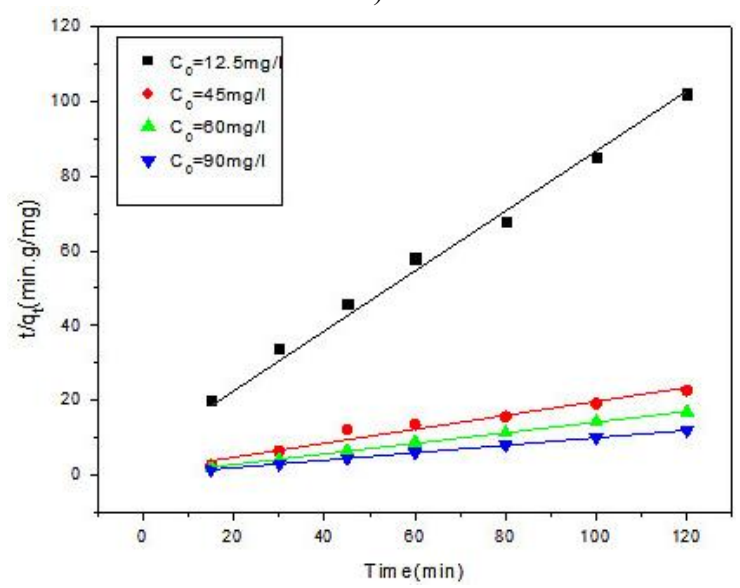

b)

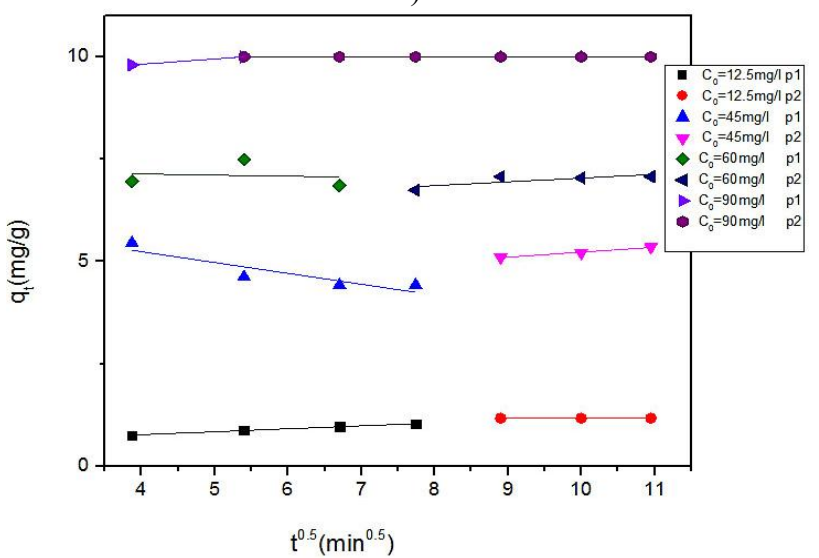

c)

Fig. 7. Adsorption kinetics of EBT: pseudo-first order kinetics (a); pseudo-second order kinetics (b); intraparticle diffusion

(c). Conditions: stirring speed $=500 \mathrm{rpm}$, sorbent dosage $=0.6 \mathrm{~g}\left(100 \mathrm{ml}^{-1}\right), T=293 \pm 2 \mathrm{~K}$, $\mathrm{pH}=6.4, d<0.315 \mathrm{~mm}$

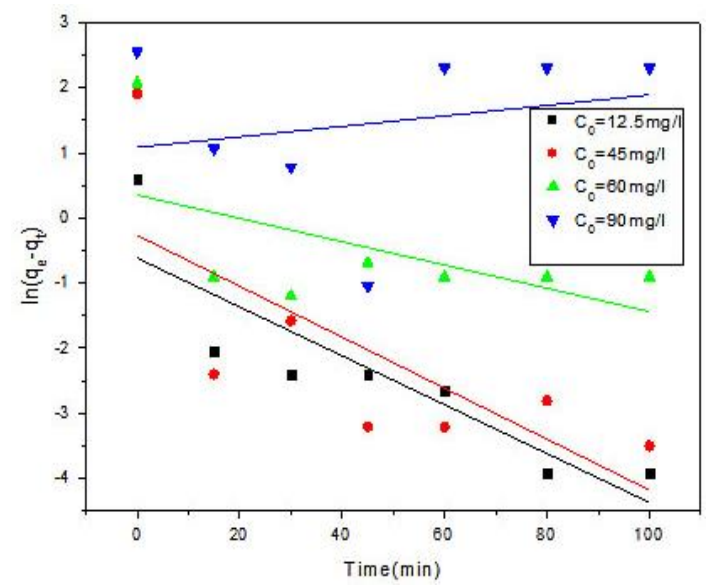

a)

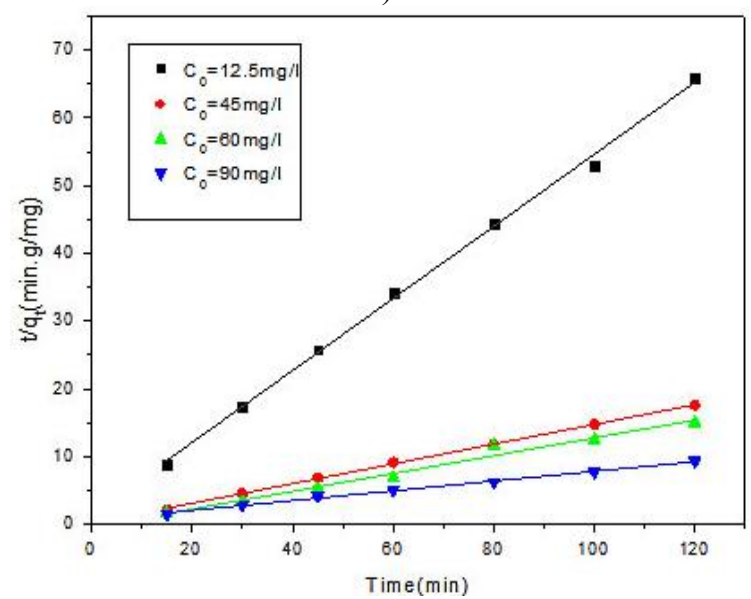

b)

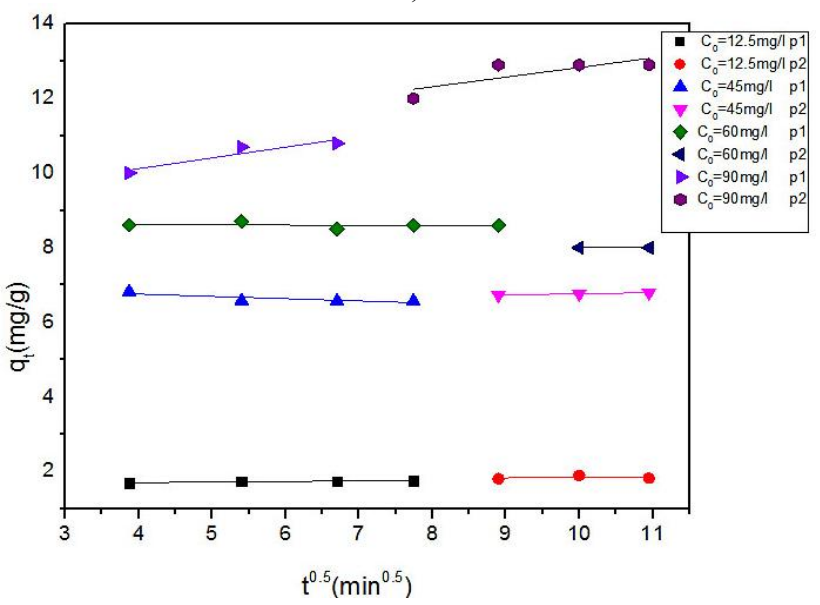

c)

Fig. 8. Adsorption kinetics of RB: pseudo-first order kinetics (a); pseudo-second order kinetics (b); intraparticle diffusion (c). Conditions: stirring speed $=500 \mathrm{rpm}$, sorbent dosage $=0.6 \mathrm{~g}\left(100 \mathrm{ml}^{-1}\right), T=293 \pm 2 \mathrm{~K}$, $\mathrm{pH}=6.4, d<0.315 \mathrm{~mm}$ 
Table 4

Kinetic parameters of EBT adsorption using M 50\% at different concentrations

\begin{tabular}{|l|c|c|c|c|}
\hline$C_{0}, \mathrm{mg} / \mathrm{l}$ & 12.5 & 45 & 60 & 90 \\
\hline$K_{1}, \mathrm{~min}^{-1}$ & 0.033 & 0.001 & 0.0328 & 0.0137 \\
\hline$q_{e}, \mathrm{mg} / \mathrm{g}$ & 2.0137 & 1.0565 & 0.8436 & 1.03045 \\
\hline$R^{2}$ & $\mathbf{0 . 3 7 1 3}$ & $\mathbf{0 . 1 7 8 5}$ & $\mathbf{0 . 4 2 1 3}$ & $\mathbf{0 . 0 5 6 5}$ \\
\hline$K_{2}, \mathrm{~g} \cdot \mathrm{mg}^{-1} \cdot \mathrm{min}^{-1}$ & 0.051 & 0.017 & 0.3923 & 0.33 \\
\hline$q_{e 2}, \mathrm{mg} / \mathrm{g}$ & 1.3333 & 5.8823 & 7.1428 & 10.0 \\
\hline$R^{2}$ & $\mathbf{0 . 9 9 5 6}$ & $\mathbf{0 . 9 6 2 1}$ & $\mathbf{0 . 9 9 8 5}$ & $\mathbf{1 . 0}$ \\
\hline$K_{i n}, \mathrm{mg} / \mathrm{g} \cdot \mathrm{min}^{0.5}$ & 0.072 & -0.265 & -0.026 & 0.0132 \\
\hline$C_{i n}, \mathrm{mg} / \mathrm{g}$ & 0.477 & 6.298 & 7.246 & 9.298 \\
\hline$R^{2}$ & $\mathbf{0 . 9 9 3 0}$ & $\mathbf{0 . 8 1 5 9}$ & $\mathbf{0 . 9 7 3 8}$ & - \\
\hline$K_{i n}, \mathrm{mg} / \mathrm{g} \cdot \mathrm{min}^{0.5}$ & 0 & 0.121 & 0.095 & $-1.16310^{-15}$ \\
\hline$C_{i n}, \mathrm{mg} / \mathrm{g}$ & 1.17 & 4.012 & 6.117 & 10.0 \\
\hline$R^{2}$ & - & $\mathbf{0 . 9 9 2 1}$ & $\mathbf{0 . 6 2 6 4}$ & - \\
\hline
\end{tabular}

Table 5

Kinetic parameters of RB adsorption using M $50 \%$ at different concentrations

\begin{tabular}{|l|c|c|c|c|}
\hline$C_{0}, \mathrm{mg} / \mathrm{l}$ & 12.5 & 45 & 60 & 90 \\
\hline$K_{1}, \mathrm{~min}^{-1}$ & 0.0375 & 0.03 & 0.01 & -0.008 \\
\hline$q_{e}, \mathrm{mg} / \mathrm{g}$ & 0.5433 & 0.7710 & 0.9900 & 2.9445 \\
\hline$R^{2}$ & $\mathbf{0 . 7 8 2 1}$ & $\mathbf{0 . 5 4 4 6}$ & $\mathbf{0 . 3 3 4 6}$ & $\mathbf{0 . 0 4 4 8}$ \\
\hline$K_{2}, \mathrm{~g} \cdot \mathrm{mg}{ }^{-1} \cdot \mathrm{min}^{-1}$ & 0.1736 & 0.1153 & 0.04 & 0.00813 \\
\hline$q_{e 2}, \mathrm{mg} / \mathrm{g}$ & 2 & 7.14 & 7.69 & 14.2 \\
\hline$R^{2}$ & $\mathbf{0 . 9 9 8 0}$ & $\mathbf{0 . 9 9 9 4}$ & $\mathbf{0 . 9 9 8 0}$ & $\mathbf{0 . 9 9 6 0}$ \\
\hline$K_{i n}, \mathrm{mg} / \mathrm{g} \cdot \mathrm{min}^{0.5}$ & 0.0150 & -0.0619 & -0.0081 & 0.0287 \\
\hline$C_{i n}, \mathrm{mg} / \mathrm{g}$ & 1.638 & 7.001 & 8.658 & 8.967 \\
\hline$R^{2}$ & $\mathbf{0 . 9 1 5 4}$ & $\mathbf{0 . 7 0 4 0}$ & $\mathbf{0 . 2 6 6 5}$ & $\mathbf{0 . 8 7 4 2}$ \\
\hline$K_{i n}, \mathrm{mg} / \mathrm{g} \cdot \mathrm{min}^{0.5}$ & 0.0117 & 0.0292 & 0.0 & 0.0258 \\
\hline$C_{i n}, \mathrm{mg} / \mathrm{g}$ & 1.724 & 6.461 & 8.0 & 10.247 \\
\hline$R^{2}$ & $\mathbf{0 . 8 7 3 8}$ & $\mathbf{0 . 9 9 8 2}$ & - & $\mathbf{0 . 4 5 1 0}$ \\
\hline
\end{tabular}

Table 6

Comparison between experimental and calculated $q_{e}$ for EBT and RB

\begin{tabular}{|c|c|c|c|}
\hline Dye & $C_{0}, \mathrm{mg} / \mathrm{l}$ & $q_{e, \text { exp }}, \mathrm{mg} / \mathrm{g}$ & $q_{e, \text { calc }}, \mathrm{mg} / \mathrm{g}$ \\
\hline \multirow{3}{*}{ EBT } & 12.5 & 1.17 & 1.3333 \\
\cline { 2 - 4 } & 45 & 5.35 & 5.8823 \\
\cline { 2 - 4 } & 60 & 7.07 & 7.1428 \\
\hline \multirow{3}{*}{ RB } & 12.5 & 1.82 & 2.0 \\
\cline { 2 - 4 } & 45 & 6.79 & 7.14 \\
\cline { 2 - 4 } & 60 & 8.0 & 7.69 \\
\hline
\end{tabular}

Table 7

Isotherms constants for EBT and RB adsorption on $\mathrm{M} 50 \%$

\begin{tabular}{|c|c|c|c|c|}
\hline \multicolumn{3}{|c|}{ EBT Adsorption on M 50\% } & \multicolumn{2}{|c|}{ RB Adsorption on M 50\% } \\
\hline Models & Constants & $R^{2}$ & Constants & $R^{2}$ \\
\hline Langmuir & $\begin{array}{l}q_{0}=34.48 \mathrm{mg} / \mathrm{g} \\
b=0.0104 \mathrm{l} / \mathrm{mg}\end{array}$ & 0.8962 & $\begin{array}{c}q_{0}=21.2 \mathrm{mg} / \mathrm{g} \\
b=0.066(\mathrm{l} / \mathrm{mg}\end{array}$ & 0.9645 \\
\hline Freundlich & $\begin{array}{c}K_{F}=0.2364 \mathrm{mg} / \mathrm{g}(\mathrm{mg} / \mathrm{l})^{1 / n} \\
n=0.8538\end{array}$ & 0.6840 & $\begin{array}{c}K_{F}=2.7556 \mathrm{mg} / \mathrm{g}(\mathrm{mg} / \mathrm{l})^{1 / n} \\
n=1.9261\end{array}$ & 0.4057 \\
\hline
\end{tabular}




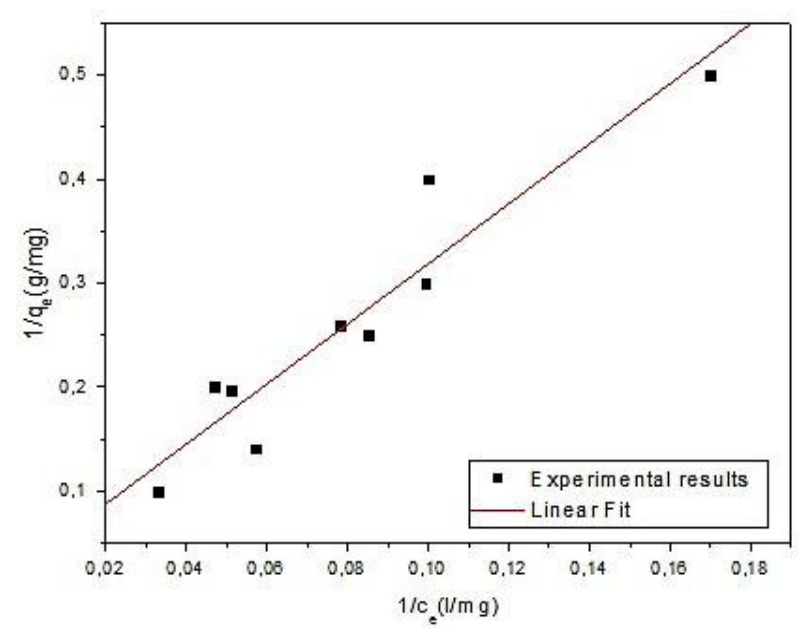

a)

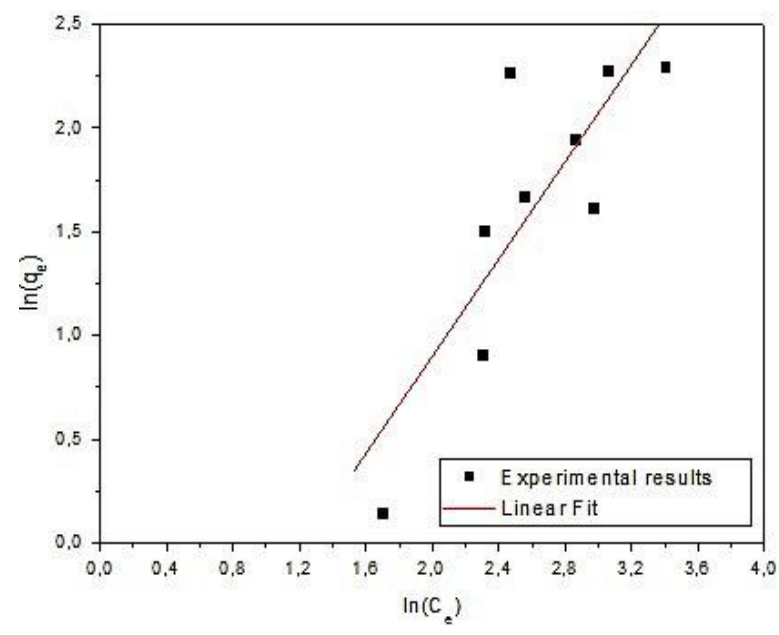

b)

Fig. 9. Linear plots of EBT: Langmuir (a) and Freundlich (b) isotherms

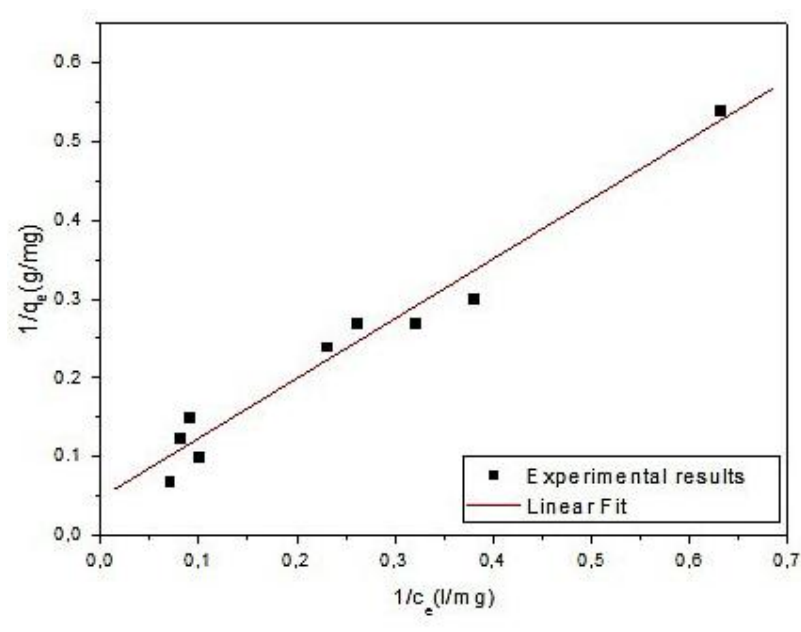

a)

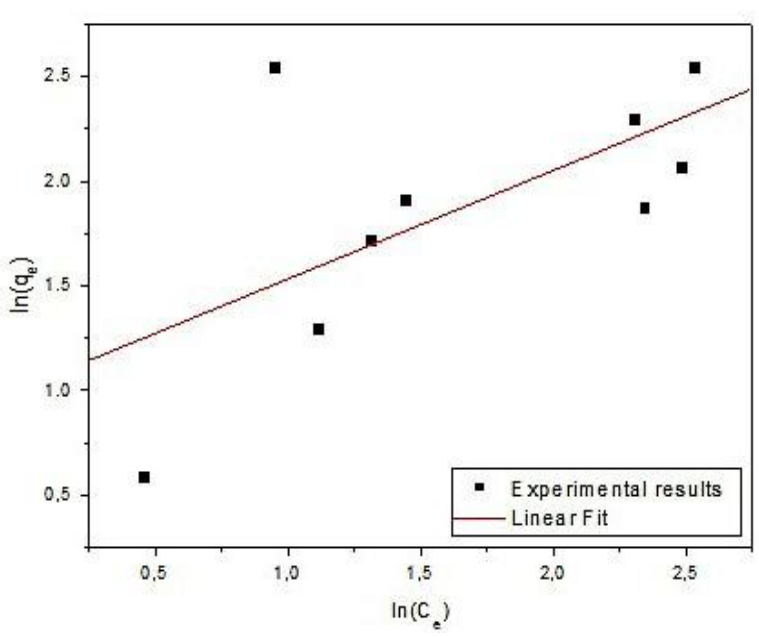

b)

Fig. 10. Linear plots of RB: Langmuir (a) and Freundlich (b) isotherms

\subsubsection{Isotherm analysis}

The EBT and RB isotherms are shown in Figs. 9 and 10, respectively. The results of this analysis are tabulated in Table 7. It can be seen that the correlation factors $R^{2}$ are close to 1 for Langmuir, so the adsorption of EBT and RB on bio-sorbent M $50 \%$ is a monolayer adsorption on homogeneous surfaces $\left(q_{0}=34.48 \mathrm{mg} / \mathrm{g}\right.$ for EBT and $q_{0}=21.2 \mathrm{mg} / \mathrm{g}$ for RB). The value of $n_{R B}$ was more than 1 , which proved the favorable adsorption.

The essential features of the Langmuir isotherm can be expressed in terms of a dimensionless constant separation factor $R_{L}$ [30]:

$$
R_{L}=\frac{1}{\left(1+b C_{0}\right)}
$$

The value of $R_{L}$ indicates the shape of the isotherms to be: unfavorable $\left(R_{L}>1\right)$, linear $\left(R_{L}=1\right)$, favorable $\left(0<R_{\mathrm{L}}<1\right)$, or irreversible $\left(R_{L}=0\right)$.

The values of $R_{L}$ observed in Fig. 11 are between $0.5-0.14$, indicating that adsorption is favorable. It is noted that when $C_{0}$ increases, $R_{L}$ approaches to zero and the adsorption becomes more favorable at high initial concentrations.

\subsubsection{Effect of temperature}

Linear plots of EBT and RB thermodynamic parameters are represented in Figs. 12-13 and Table 8. For EBT (according to Table 8) the positive values of $\Delta G$ indicate the slow nature of the process [31]. The enthalpy $\Delta H$ was found to be positive as well, confirming the endo- 
thermic nature of the dye adsorption process within the temperature interval of $293-313 \mathrm{~K}$; the variation of enthalpy $\Delta H$ in the interval of $40-120 \mathrm{~kJ} / \mathrm{mol}$ suggests that the adsorption system may be of chemical nature (chemisorption); the physical sorption is characterized by values of $\Delta H(<40 \mathrm{~kJ} / \mathrm{mol})$, so the calculated value of $12.31 \mathrm{~kJ} / \mathrm{mol}$ indicates clearly the physical sorption [32]. The positive value of $\Delta S$ reflects the increased randomness of the solid-solution interface [33].

In the case of $\mathrm{RB}$ the negative values of $\Delta G$ indicate that the process is spontaneous [31]. The enthalpy $\Delta H$ is positive confirming the endothermic nature of dye adsorption in the interval of $293-313 \mathrm{~K}$. The value of enthalpy $26.8 \mathrm{~kJ} / \mathrm{mol}$ indicates that the adsorption of RB on $\mathrm{M} 50 \%$ is a physical sorption [32], the same variation of $\Delta S$ for EBT [33].

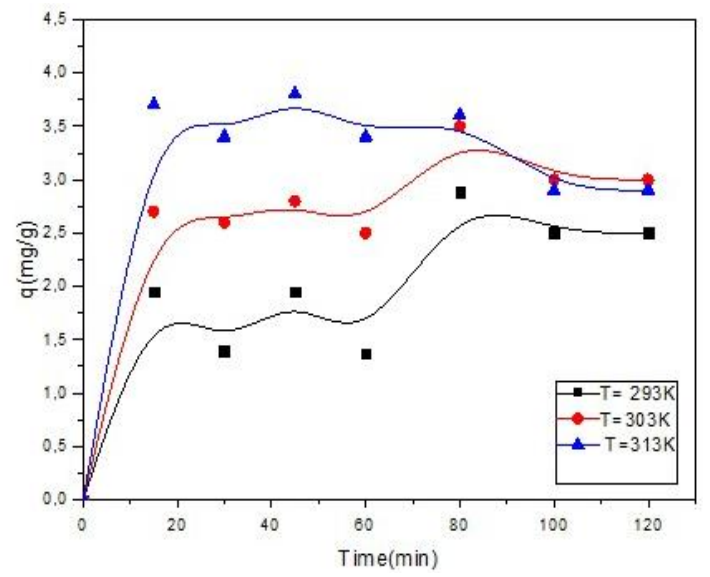

a)

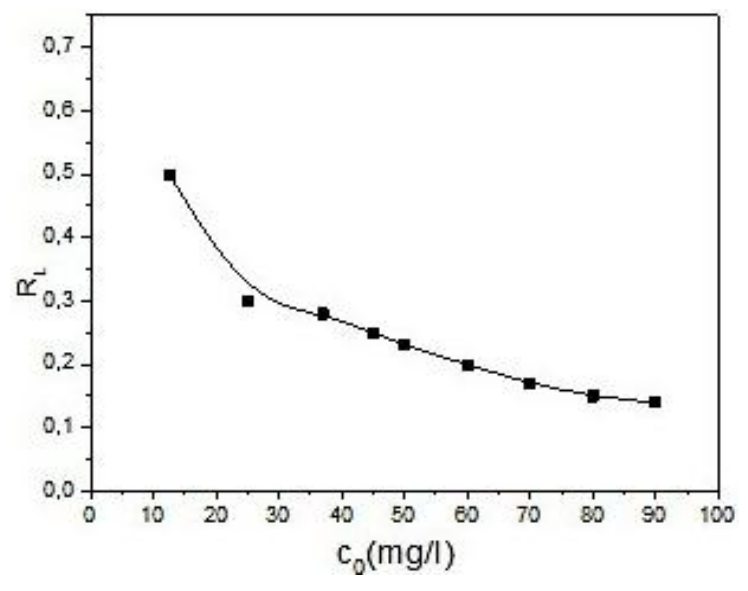

Fig. 11. Separation factor RL of RB adsorption on $\mathrm{M} 50 \%$

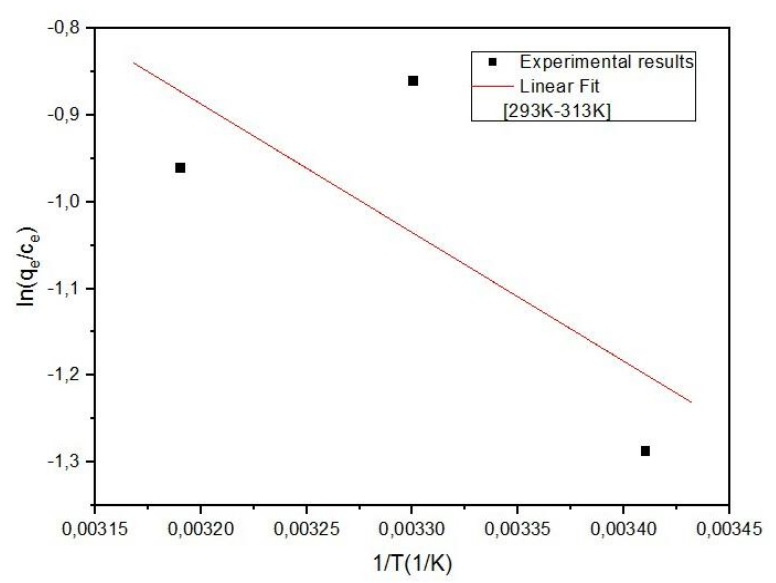

b)

Fig. 12. Temperature effect (a) and linear plot of thermodynamic parameters for EBT. Conditions: $C_{0}=25 \mathrm{mg} / \mathrm{l}$, stirring speed $=500 \mathrm{rpm}$, sorbent dosage $=0.6 \mathrm{~g}\left(100 \mathrm{ml}^{-1}\right), \mathrm{pH}=6.4, d<0.315 \mathrm{~mm}$

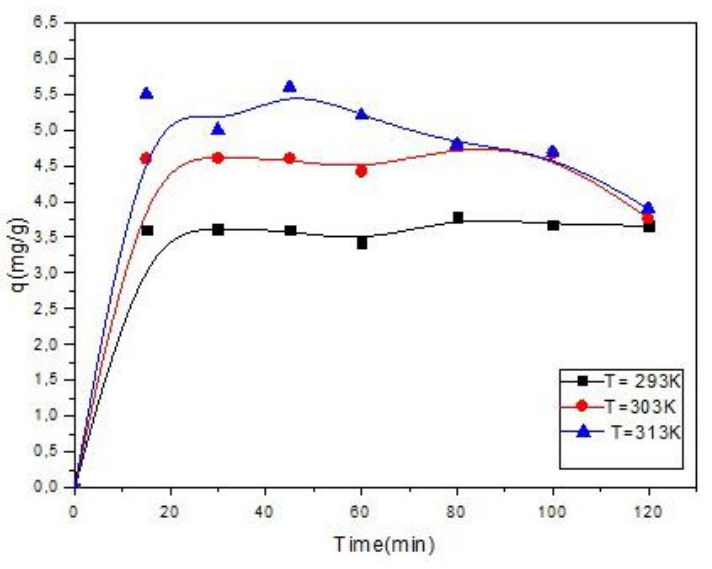

a)

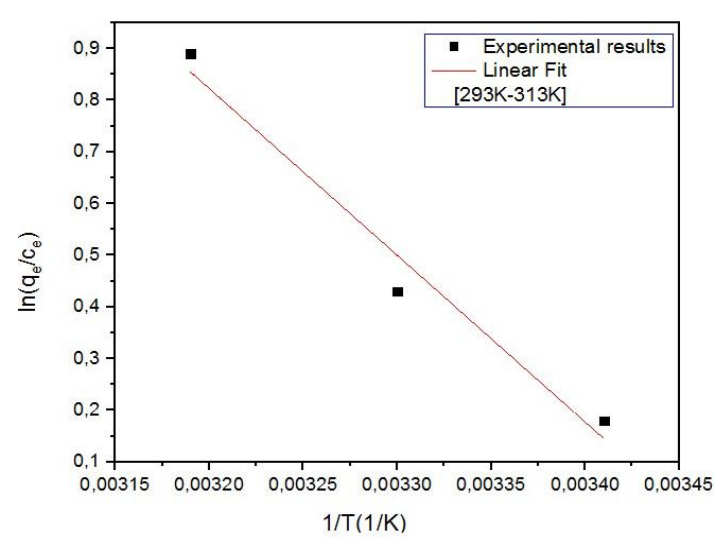

b)

Fig. 13. Temperature effect (a) and linear plot of thermodynamic parameters for RB. Conditions: $C_{0}=25 \mathrm{mg} / \mathrm{l}$, stirring speed $=500 \mathrm{rpm}$, sorbent dosage $=0.6 \mathrm{~g}\left(100 \mathrm{ml}^{-1}\right), \mathrm{pH}=6.4, d<0.315 \mathrm{~mm}$ 
Thermodynamic parameters of EBT and RB adsorption on M 50\%

\begin{tabular}{|c|c|c|c|c|}
\hline Dye & $T, \mathrm{~K}$ & $\Delta G, \mathrm{~kJ} / \mathrm{mol}$ & $\Delta H, \mathrm{~kJ} / \mathrm{mol}$ & $\Delta S, \mathrm{~kJ} / \mathrm{mol} \cdot \mathrm{K}$ \\
\hline \multirow{3}{*}{ EBT } & 293 & 2.93 & \multirow{3}{*}{12.31} & \multirow{3}{*}{0.03199} \\
\hline & 303 & 2.61 & & \\
\hline & 313 & 2.29 & & \\
\hline \multirow{3}{*}{$\mathrm{RB}$} & 293 & -0.156 & \multirow{3}{*}{26.8} & \multirow{3}{*}{0.092} \\
\hline & 303 & -1.076 & & \\
\hline & 313 & -1.99 & & \\
\hline
\end{tabular}

\section{Conclusions}

The results obtained show that $\mathrm{M} 50 \%$ composed of PPRS and EGRS (50:50) is an efficient sorbent for the removal of mixture dyes (EBT, RB) from aqueous solutions. The FTIR and XRD characterization confirmed that $\mathrm{M} 50 \%$ is composed of calcite $\left(\mathrm{CaCO}_{3}\right)$ and cellulose. The study considered the effect of different physicochemical parameters on EBT and RB retention such as $\mathrm{pH}$, effect of ionic strength, etc. The adsorbed amounts for EBT and RB increased due to the presence of salts. The kinetic study showed that adsorption follows a second order model. The equilibrium results were evaluated according to the Langmuir and Freundlich isotherms. The Langmuir model was found to be in a good agreement with experimental data.

\section{Acknowledgments}

The authors are grateful to the Algerian Ministry of Higher Education and Scientific Research for financial support.

\section{References}

[1] Gezer B.: Int. J. Agric. For. Life Sci., 2018, 2, 1.

[2] Benkartoussa Z., Karima B., Mossaab B.: JDOC, 2015, 1, 10.

http://jdoc.sawis.org

[3] Djebbar M., Djafri F.: Chem. Chem. Technol., 2018, 12, 272. https://doi.org/10.23939/chcht12.02.272

[4] Erguler G.: Miner. Eng., 2015,76, 10.

https://doi.org/10.1016/j.mineng.2015.02.002

[5] Khademolhosseini M. Mobasherpour I., Ghahremani D.: Chem.

Chem. Technol., 2018, 12, 372.

https://doi.org/10.23939/chcht12.03.372

[6] Sabadash V., Mylanyk O., Matsuska O., Gumnitsky J.: Chem.

Chem. Technol., 2017, 11, 459.

https://doi.org/10.23939/chcht11.04.459

[7] Benkartoussa M., Lehocine B.: Algerian J. Eng. Res., 2018, 2, 45 .

[8] Shachneva E., Archibasova D.: Chem. Chem. Technol., 2018, 12, 182. https://doi.org/10.23939/chcht12.02.182

[9] Al Azabi K., Al Marog S., Abukrain A., Sulyman M.: Chem. Res. J., 2018, 3, 45.
[10] Ekpete O., Horsfall M.: Res. J. Chem. Sci., 2011, 3, 10. [11] Gupta N., Kushwaha A., Chattopadhyaya M.: Arabian J. Chem., 2016, 9, 707. https://doi.org/10.1016/j.arabjc.2011.07.021 [12] Gravereau P.: La diffraction des rayons x par les poudres, ICMCB-CNRS, Université Bordeaux 1, 2012.

[13] Samarghandy M., Hoseinzade E. et al.: BioRes., 2011, 6, 4840.

[14] Weber W.: Physicochemical Processes: for Water Quality Control. Wiley, New York 1972.

[15] Abbas A., Jaafar M., Ismail A.., Wan Sulaiman W.: Chem. Eng. Transact., 2017, 56, 151. https://doi.org/10.3303/CET1756026 [16] Crini G.: Dyes Pigm., 2008, 77, 415. https://doi.org/10.1016/j.dyepig.2007.07.001

[17] Nethaji S., Sivasamy A., Mandal A.: Int. J. Environ. Sci. Technol., 2013, 10, 231. https://doi.org/10.1007/s13762-012-0112-0

[18] Bellir K., Sadok Bouziane I., Boutamine Z. et al.: Energy

Procedia, 2012, 18, 924.

https://doi.org/10.1016/j.egypro.2012.05.107

[19] Flores-Cano J., Leyva-Ramos R., Mendoza-Barron J. et al.: Appl. Surf. Sci., 2013, 276, 682.

https://doi.org/10.1016/j.apsusc.2013.03.153

[20]

http://r.chouchi.free.fr/modeles $\% 20$ moleculaires/frequences.html [21] Lotfi M.: Cours de Spectroscopie IR, Maitres de conférences classe A, Directeur du laboratoire de recherche LGVRNAQ,

[22] Taleb H., Chehade Y., Abou Zour M.: Int. J. Electrochem. Sci., $2011,6,6542$.

[23] Bousba S., Bougdah N., Messikh N., Magri P.: Phys. Chem. Res., 2018, 6, 613. https://doi.org/10.22036/pcr.2018.129154.1482 [24] Raclot C.: Dosage des ions Nickel (II) par l'ETDA, concours aggregation interne , ancient professeur du lycée des haberges 20014 Vesoul France 2011.

[25] Larakeb M., Youcef L., Achour S.: J. New Technol. Mater., 2016, 6, 19. https://doi.org/10.12816/0043919

[26] Larous S., Meniai A.: Energy Procedia, 2012, 18, 915. https://doi.org/10.1016/j.egypro.2012.05.106

[27] Nandhakumar V., Rajathi A., Venkatachalam R. et al.: SOJ

Mater. Sci. Eng., 2015, 1.

https://doi.org/10.15226/sojmse.2016.00121

[28] Alberghina G., Bianchini R., Fichera M., Fisichella S.: Dyes Pigm., 2000, 46, 129. https://doi.org/10.1016/S0143-

7208(00)00045-0

[29] Hameed B., Tan I., Ahmad A.: Chem. Eng. J., 2008, 144, 235. https://doi.org/10.1016/j.cej.2008.01.028

[30] Hall K., Eagleton L., Acrivos A., Vermeulen T.: Ind. Eng.

Chem. Fundamen., 1966, 5, 212.

https://doi.org/10.1021/i160018a011

[31] Al-Muhtaseb A., Ibrahim K., Albadarin A. et al.: Chem. Eng. J., 2011, 168, 691. https://doi.org/10.1016/j.cej.2011.01.057

[32] Wu F., Tseng R., Juang R.: Environ. Technol., 2001, 22, 721. https://doi.org/10.1080/09593332208618235 
Adsorption Removal of Eriochrome Black T (EBT) and Rose Bengal (RB) from Aqueous Solutions...

[33] Belaid K., Kacha S.: J. Water Sci., 2011, 24,131.

https://doi.org/10.7202/1006107ar

Received: February 14, 2019 / Revised: March 13, 2019 / Accepted: March 18, 2019

\section{ВИДАЛЕННЯ ЕРІОХРОМУ ЧОРНОГО Т I БЕНГАЛЬСЬКОГО РОЖЕВОГО 3 ВОДНИХ РОЗЧИНІВ $З$ ВИКОРИСТАННЯМ СУМІШІ БIOСОРБЕНТIB}

Анотація. Адсорбиію барвників еріохрому чорного $T$ (ЕЧТ) та бенгальського рожевого (БР) з водних розчинів проведено з використанням сумімі (50:50) недорогих біосорбентів кожури картоплі та яєчної шкарлупи (М 50\%). Кислотноосновним титруванням встановлений розподіл поверхневого заряду, а точка нульового заряду М 50\% дорівнюе 8,5. Характеристику адсорбентів визначено за допомогою Фур 'є-спектроскопї та рентгеноструктурного аналізу. Встановлено, щзо М 50\% переважно складається з кальциту та иелюлози. Вивчено вплив різних робочих параметрів, таких як час контакту, рН, температура тощо. Доведено, щуо адсорбиія зменшується з підвищенням рН розчину. Показано, щзо кінетична модель псевдодругого порядку найкраще узгоджсється з експериментальними даними адсорбиії ЕЧТ та БР. Отримані термодинамічні параметри вказують на те, изо адсорбиійний прочес $\epsilon$ ендотермічним. Рекомендовано використовувати комбінований біосорбент у промисловості для очищення стоків, щуо містять ЕЧТ та БР.

Ключові слова: барвник, комбінація, адсорбент, Фур'єспектроскопія, рентгеноструктурний аналіз. 